\title{
CXCL8 and CXCL11 chemokine secretion in dermal fibroblasts is differentially modulated by vanadium pentoxide
}

\author{
P. FALLAHI ${ }^{1}$, R. FODDIS ${ }^{1}$, G. ELIA ${ }^{2}$, F. RAGUSA ${ }^{2}$, A. PATRIZIO ${ }^{2}$, \\ S. BENVENGA ${ }^{3-5}$, A.CRISTAUDO ${ }^{1}$, A. ANTONELLI ${ }^{2}$ and S. M. FERRARI ${ }^{2}$ \\ ${ }^{1}$ Department of Translational Research and New Technologies in Medicine and Surgery; \\ ${ }^{2}$ Department of Clinical and Experimental Medicine, School of Medicine, University of Pisa, I-56126 Pisa; \\ ${ }^{3}$ Department of Clinical and Experimental Medicine, University of Messina; ${ }^{4}$ Master Program on Childhood, \\ Adolescent and Women's Endocrine Health; ${ }^{5}$ Interdepartmental Program of Molecular and Clinical Endocrinology and \\ Women's Endocrine Health, Azienda Ospedaliera Universitaria Policlinico ‘G. Martino’, I-98125 Messina, Italy
}

Received November 1, 2017; Accepted April 16, 2018

DOI: $10.3892 / \mathrm{mmr} .2018 .9121$

\begin{abstract}
An increase in skin rashes or atopic dermatitis has been observed in individuals working with vanadium. However, to the best of our knowledge no in vivo or in vitro studies have evaluated the effect of exposure to vanadium in dermal fibroblasts. Cells viability and proliferation were assessed by WST-1 assay, cells were treated with increasing concentrations of $\mathrm{V}_{2} \mathrm{O}_{5}$ (1, 10 and $100 \mathrm{nM})$. CXCL8 and CXCL11 concentrations were measured in the supernatants using an ELISA assay. $\mathrm{V}_{2} \mathrm{O}_{5}$ was not observed as having a significant effect on dermal fibroblast's viability and proliferation. However, it was revealed that $\mathrm{V}_{2} \mathrm{O}_{5}$ was able to induce the secretion of CXCL8 and CXCL11 chemokines into dermal fibroblasts. $\mathrm{V}_{2} \mathrm{O}_{5}$ synergistically increased the effect of interferon (IFN) $\gamma$ on CXCL11 secretion. In addition, $\mathrm{V}_{2} \mathrm{O}_{5}$ synergistically increased the effect of the tumor necrosis factor $\alpha$ on CXCL8 secretion and abolished the inhibitory effect of IFN $\gamma . \mathrm{V}_{2} \mathrm{O}_{5}$ induction of CXCL8 and CXCL11 chemokines may lead to the appearance and perpetuation of an inflammatory reaction into the dermal tissue. Further studies are required to evaluate dermal integrity and manifestations in subjects occupationally exposed, or living in polluted areas.
\end{abstract}

\section{Introduction}

Vanadium is a grey metal that exists in different states of oxidation (ranging from -1 to +5 ) of which vanadium pentoxide $\left(\mathrm{V}_{2} \mathrm{O}_{5}\right)$ is the most usual form.

All vanadium compounds have been considered toxic. The exposure limit to $\mathrm{V}_{2} \mathrm{O}_{5}$ dust and fumes in workplace

Correspondence to: Dr Alessandro Antonelli, Department of Clinical and Experimental Medicine, School of Medicine, University of Pisa, 10 Via Savi, I-56126 Pisa, Italy

E-mail: alessandro.antonelli@med.unipi.it

Key words: vanadium, CXCL8, CXCL11, chemokines, dermal fibroblasts, environmental exposure, occupational exposure air ( $8 \mathrm{~h}$ work day/40 h work week) has been fixed by the Occupational Safety and Health Administration in 0.05 and $0.1 \mathrm{mg} / \mathrm{m}^{3}$, respectively (1).

The National Institute for Occupational Safety and Health (NIOSH) sets to $35 \mathrm{mg} / \mathrm{m}^{3}$ the dose of vanadium exposure that may cause seriously health issues up to death (1).

Toxic effects of vanadium are reflected mainly on respiratory system, while the effect on the gastrointestinal system is less relevant because of the minimal gut absorption rate of the substance (2-4). Unfortunately, no sufficient data are available in order to determine the reference range of a subchronic or chronic inhaled dose.

Studies conducted on rat models showed the toxic effects (resulted from an oral, or inhaled, vanadium exposures) on serum parameters $(5,6)$, liver (7), nervous (8) and other tissues development (9).

Vanadium workers (NIOSH 1983) showed an increased prevalence of skin rashes, such as atopic dermatitis.

Until now no in vivo, or in vitro, studies were carried out to evaluate the effect of exposure to vanadium in dermal fibroblasts.

Here, we evaluate the effect of $\mathrm{V}_{2} \mathrm{O}_{5}$ on viability and proliferation, and secretion of chemokine (C-X-C motif) ligand (CXCL)8, or CXCL11 [an interferon (IFN) $\gamma$ dependent chemokine, of the same class of CXCL9, and CXCL10] in dermal human fibroblasts.

\section{Materials and methods}

Fibroblast cell cultures. We have obtained fibroblasts from derma of six patients who underwent an operation for thyroid nodular goiter (discard dermal material; all females, age range 57-76 years, euthyroid, without other disorders or diseases, and not treated with any kind of drugs).

Involved subjects gave their informed consent and the study was approved by the University of Pisa (Pisa, Italy) Ethics Committee. Tissue explants were firstly minced and then placed in culture dishes, allowing the fibroblasts proliferation (as previously described) (10). Fibroblasts were propagated in 199 medium [with 20\% FBS (Gibco; Thermo Fisher Scientific, 
Waltham, MA, USA), gentamycin $(20 \mu \mathrm{g} / \mathrm{ml})$, penicillin $(100 \mathrm{U} / \mathrm{ml})]$, in a $37^{\circ} \mathrm{C}$ humidified incubator with $5 \% \mathrm{CO}_{2}$; and maintained subsequently in a 199 medium with $10 \%$ FBS (and antibiotics) (11). The cells were all used at the 4th passage, and were tested for purity by immunocytochemistry (12).

Proliferation and viability. We have done the WST-1 (Roche Diagnostics, Almere, The Netherlands) assay (that uses 3-[4,5-dimethylthiazol-2-yl]-2,5-diphenyltetrazolium bromide, in the MTT assay) to evaluate cell viability and proliferation (13-16).

Firstly fibroblasts were seeded in each well of 96-well plates at a concentration of 35,000 cells $/ \mathrm{ml}$ (in a final volume of $100 \mu 1$ ).

Subsequently $\mathrm{V}_{2} \mathrm{O}_{5}$ effect on fibroblasts viability and proliferation was determined exposing cells for $24 \mathrm{~h}$ with increased concentrations of the compound (1, 10, $100 \mathrm{nM})$.

Fibroblasts were plated and treated with $\mathrm{V}_{2} \mathrm{O}_{5}$ or with its vehicle alone (for $24 \mathrm{~h}$ ), performing all experiments in triplicate for each cell preparation.

As the cell viability and proliferation WST-1 assay may have limitations on evaluating cellular proliferation (17), fibroblasts proliferation was determined also by cell number counting (13-16).

Chemokine secretion assay and ELISA. To perform the CXCL8 and CXCL11 secretion assays, 30,000 cells $/ \mathrm{ml}$ were seeded in 96-well plates, in a final volume of $100 \mu \mathrm{l}$ per well, in growth medium, that was removed after $24 \mathrm{~h}$. After cells were washed in PBS, and incubated ( $24 \mathrm{~h})$ in phenol red and serum-free medium containing IFN $\gamma(500,1,000,5,000,10,000 \mathrm{IU} / \mathrm{ml})$ and/or $10 \mathrm{ng} / \mathrm{ml} \mathrm{TNF} \alpha$ (all R\&D Systems, Minneapolis, MN, USA), alone or in combination (10). The TNF $\alpha$ concentration to obtain the highest secretion was selected in preliminary experiments. After 1 day the supernatants were collected and then kept frozen at $-20^{\circ} \mathrm{C}$ (until chemokine assay).

We treated fibroblasts, for $24 \mathrm{~h}$, with increasing concentrations of $\mathrm{V}_{2} \mathrm{O}_{5}(1,10,100 \mathrm{nM})$, in presence/absence of IFN $\gamma$ $(1,000 \mathrm{IU} / \mathrm{ml})$, and/or TNF $\alpha(10 \mathrm{ng} / \mathrm{ml})$, in order to evaluate the effect of $\mathrm{V}_{2} \mathrm{O}_{5}$ on the chemokine secretion induced by IFN $\gamma$.

CXCL8 and CXCL11 concentrations were measured in the supernatants using the ELISA assay. The experiments were carried out three times, for each different cell preparation.

Chemokines levels were measured in culture supernatants, using commercially kits (R\&D Systems). The mean minimum detectable dose was $2.7 \mathrm{pg} / \mathrm{ml}$ for CXCL8 and $3.2 \mathrm{pg} / \mathrm{ml}$ for CXCL11; the intra- and inter-assay coefficients of variation were 3.5 and $6.5 \%$ for CXCL8, 4.7 and $8.5 \%$ for CXCL11. Quality control pools of low, normal, or high concentration for all parameters were included in each assay.

Statistical analysis. For normally distributed variables values are given in text as mean $( \pm \mathrm{SD})$, or mean $( \pm \mathrm{SEM})$ in figures, otherwise as median [and interquartile range]. Mean group values are compared by one-way analysis of variance (ANOVA) for variables normally distributed, or with the Kruskal-Wallis test, or Mann-Whitney U test. Proportions are compared by the Chi-Square. We have used the Bonferroni-Dunn test for post hoc comparison of normally distributed variables.

\section{Results}

Cell proliferation of dermal fibroblasts. Cell counting shows that $\mathrm{V}_{2} \mathrm{O}_{5}(1,10,100 \mathrm{nM})$ does not change viability or proliferation of dermal fibroblasts (Fig. 1). The results of WST-1 assay in dermal fibroblasts with $\mathrm{V}_{2} \mathrm{O}_{5}(1,10,100 \mathrm{nM})$ confirmed the cell counting data: with $\mathrm{V}_{2} \mathrm{O}_{5} 1 \mathrm{nM}$ it was $99 \%$ with respect to the control; with $\mathrm{V}_{2} \mathrm{O}_{5} 10 \mathrm{nM}$ it was $97 \%$ with respect to the control; and with $\mathrm{V}_{2} \mathrm{O}_{5} 100 \mathrm{nM}$ it was $98 \%$ with respect to the control.

Fibroblast secretion of CXCL8. In basal conditions, the secretion of CXCL8 (range, 51-213 pg/ml) was measured in all preparations of cultured dermal fibroblasts (Fig. 2).

CXCL8 secretion increased in a dose-dependent manner using different concentrations of $\operatorname{TNF} \alpha(1,5,10 \mathrm{ng} / \mathrm{ml})$, with the highest response reached with $10 \mathrm{ng} / \mathrm{ml} \mathrm{TNF} \alpha$ (basal $156 \pm 46 \mathrm{pg} / \mathrm{ml}$ vs. TNFa $1154 \pm 321 \mathrm{pg} / \mathrm{ml}$; P<0.01) (Fig. 2).

The basal CXCL8 secretion was significantly inhibited by IFN $\gamma$ in a dose-dependent manner (CXCL8: 84 $\pm 37,34 \pm 25, \mathrm{pg} / \mathrm{ml}$; respectively, with IFN $\gamma 500$ or 1,000 IU/ml; ANOVA, P<0.05), while $\mathrm{TNF} \alpha$ alone $(10 \mathrm{ng} / \mathrm{ml})$ significantly stimulated the CXCL8 secretion $(\mathrm{P}<0.01)$ (Fig. 3). Combining IFN $\gamma$ with $\mathrm{TNF} \alpha$ led to a significant reversal of the stimulating effect of $\mathrm{TNF} \alpha(\mathrm{TNF} \alpha+\mathrm{IFN} \gamma 661 \pm 176 \mathrm{pg} / \mathrm{ml}$ vs. TNF $\alpha 1154 \pm 321 \mathrm{pg} / \mathrm{ml}$; $\mathrm{P}<0.05$ ) (Fig. 3). However, the stimulating effect of $\mathrm{TNF} \alpha$ on the secretion of CXCL8 was not completely reversed by IFN $\gamma$, because the concentration of this chemokine was still significantly higher than in basal conditions (TNF $\alpha+\mathrm{IFN} \gamma$ vs. basal; $\mathrm{P}<0.01)$.

When fibroblasts were treated with increased $\mathrm{V}_{2} \mathrm{O}_{5}$ concentrations $(1,10,100 \mathrm{nM})$ the CXCL8 release was dose-dependently stimulated ( $\mathrm{P}<0.0001$, by ANOVA) (Fig. 4).

When treating dermal fibroblasts with $\mathrm{V}_{2} \mathrm{O}_{5}(100 \mathrm{nM})$, together with IFN $\gamma$, CXCL8 release was not significantly changed with respect to the basal condition, and IFN $\gamma$ suppressed the $\mathrm{V}_{2} \mathrm{O}_{5}$ stimulating effect, but it stills increased it compared to IFN $\gamma$ alone (Fig. 5).

$\mathrm{V}_{2} \mathrm{O}_{5}(100 \mathrm{nM})$ plus $\mathrm{TNF} \alpha$ elicited a synergistic effect on CXCL8 secretion ( $\mathrm{P}<0.0001$, by ANOVA), compared to TNF $\alpha$ alone (Fig. 6).

The CXCL8 release synergistically increased $(\mathrm{P}<0.0001$, by ANOVA), when fibroblasts were treated with $\mathrm{V}_{2} \mathrm{O}_{5}$ $(100 \mathrm{nM})$ with the combination of IFN $\gamma$ and TNF $\alpha$, abolishing the inhibitory effect of IFN $\gamma$ (Fig. 7).

Fibroblast secretion of CXCL11. CXCL11 release was inducted by IFN $\gamma$ in a dose-dependent manner (CXCL11: 0, $31 \pm 17,87 \pm 35,123 \pm 47,187 \pm 52 \mathrm{pg} / \mathrm{ml}$; respectively, with IFN $\gamma$ 0, 500, 1,000, 5,000, 10,000 IU/ml; ANOVA, P<0.001).

TNF $\alpha$ alone had no effect (chemokine remaining undetectable), while the combination of IFN $\gamma$ and TNF $\alpha$ had a significant synergistic effect on the CXCL11 secretion (CXCL11, 1724 \pm 252 vs. $87 \pm 35 \mathrm{pg} / \mathrm{ml}$ with IFN $\gamma$ alone, ANOVA, $\mathrm{P}<0.0001)$.

When fibroblasts were treated with increased $\mathrm{V}_{2} \mathrm{O}_{5}$ concentrations $(1,10,100 \mathrm{nM})$ the CXCL11 release was dose-dependently stimulated (ANOVA, P<0.0001) (Fig. 8).

CXCL11 release was not significantly changed treating cells with $\mathrm{V}_{2} \mathrm{O}_{5}(100 \mathrm{nM})$, together with $\mathrm{TNF} \alpha$, with respect to $\mathrm{V}_{2} \mathrm{O}_{5}$ alone (data not shown). 


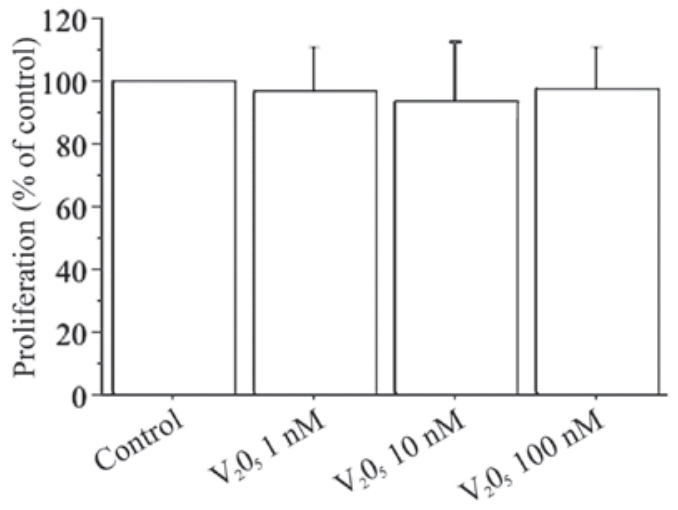

Figure $1 . \mathrm{V}_{2} \mathrm{O}_{5}$ treatment does not significantly change the proliferation of dermal fibroblasts (mean group values are compared using one-way analysis of variance; the Bonferroni-Dunn test was used for post-hoc comparison; $\mathrm{P}>0.05$, for all comparisons). $\mathrm{V}_{2} \mathrm{O}_{5}$, vanadium pentoxide.

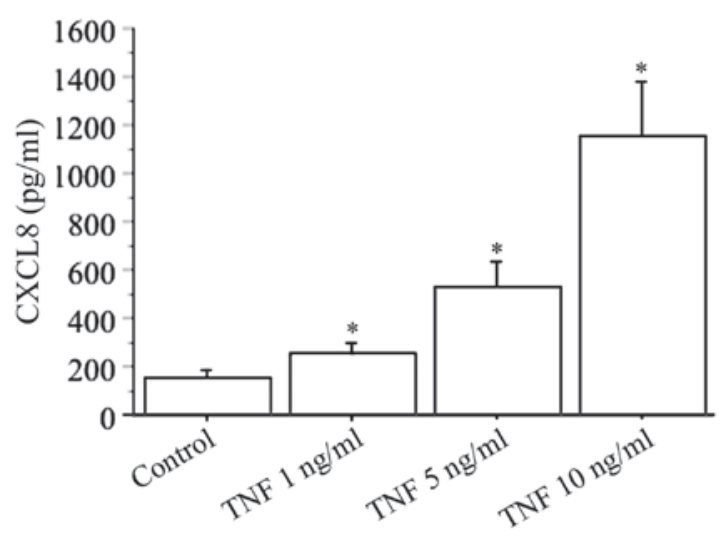

Figure 2. CXCL8 secretion was measured in all cultured dermal fibroblasts preparations in basal conditions (control); its secretion increased significantly and dose-dependently with different concentrations of TNFa $(1,5$ and $10 \mathrm{ng} / \mathrm{ml}$ ) (the Bonferroni-Dunn test was used for post-hoc comparison). ${ }^{*} \mathrm{P}<0.05$ vs. control. TNF, tumor necrosis factor.

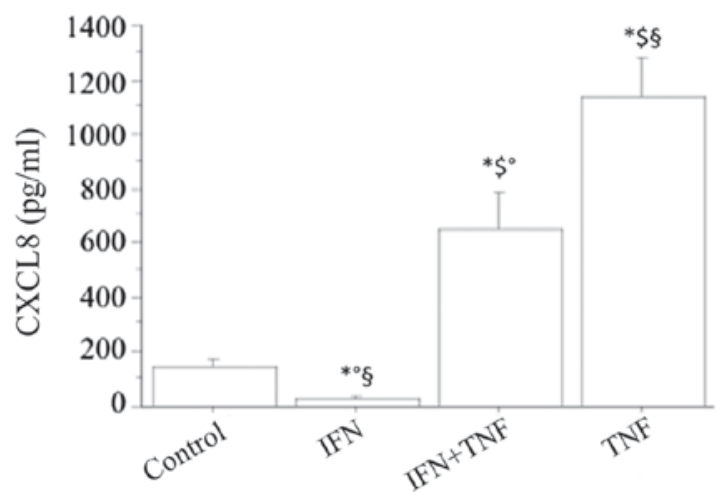

Figure 3. IFN $\gamma(1,000 \mathrm{IU} / \mathrm{ml})$ significantly inhibited the basal CXCL8 secretion. The stimulating effect of TNF $\alpha$ was significantly reversed after the addition of IFN $\gamma$ (the Bonferroni-Dunn test was used for post-hoc comparison; " $\mathrm{P}<0.05$ vs. Control; ${ }^{\circ} \mathrm{P}<0.05$ vs. TNF; ${ }^{\circledR} \mathrm{P}<0.05$ vs. IFN+TNF; ${ }^{\$} \mathrm{P}<0.05$ vs. IFN). IFN, interferon; TNF, tumor necrosis factor.

When treating fibroblasts with $\mathrm{V}_{2} \mathrm{O}_{5}(100 \mathrm{nM})$, plus IFN $\gamma$, CXCL11 release synergistically increased $(\mathrm{P}<0.0001$, by ANOVA), compared to both IFN or $\mathrm{V}_{2} \mathrm{O}_{5}$ alone (Fig. 9).

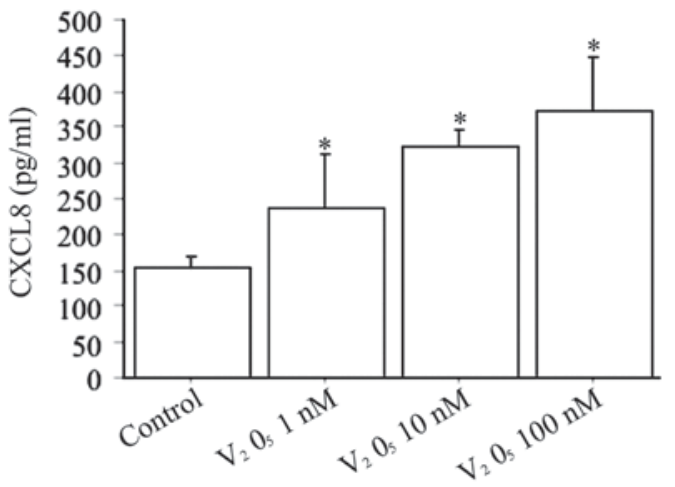

Figure 4. CXCL8 release was dose-dependently stimulated by treating dermal fibroblasts with $\mathrm{V}_{2} \mathrm{O}_{5}(1,10$ and $100 \mathrm{nM})$. " $\mathrm{P}<0.05$ vs. control (the Bonferroni-Dunn test was used for post-hoc comparison). $\mathrm{V}_{2} \mathrm{O}_{5}$, vanadium pentoxide.

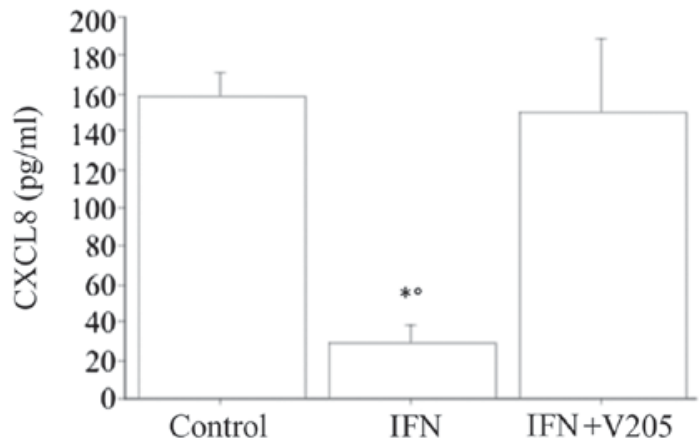

Figure 5. Treatment of dermal fibroblasts with $\mathrm{V}_{2} \mathrm{O}_{5}(100 \mathrm{nM})$ abolished the inhibitory effect of IFN $\gamma$ (the Bonferroni-Dunn test was used for post-hoc comparison; ${ }^{*} \mathrm{P}<0.05$ vs. Control; ${ }^{\circ} \mathrm{P}<0.05$ vs. IFN $+\mathrm{V}_{2} 0_{5}$ ). $\mathrm{V}_{2} \mathrm{O}_{5}$, vanadium pentoxide; IFN, interferon.

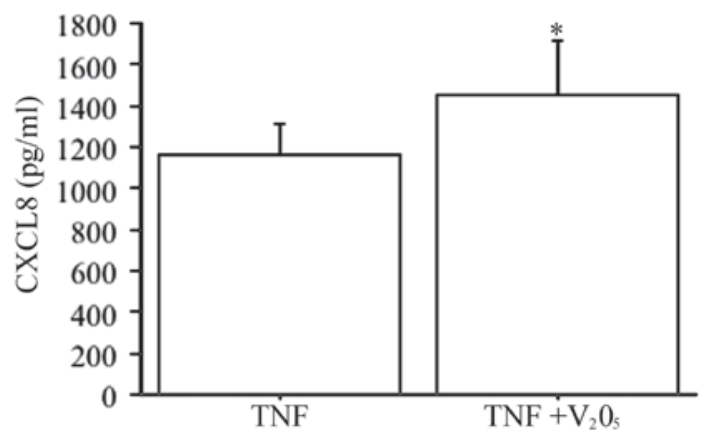

Figure 6. CXCL8 release was significantly increased by treating dermal fibroblasts with $\mathrm{V}_{2} \mathrm{O}_{5}(100 \mathrm{nM})$ and $\mathrm{TNF} \alpha$. ${ }^{*} \mathrm{P}<0.05$ vs. the TNF group. $\mathrm{V}_{2} \mathrm{O}_{5}$, vanadium pentoxide; TNF, tumor necrosis factor.

CXCL11 release was synergistically increased (ANOVA, $\mathrm{P}<0.0001)$ when fibroblasts were treated with $\mathrm{V}_{2} \mathrm{O}_{5}(100 \mathrm{nM})$, together with IFN $\gamma$ and TNF $\alpha$ stimulation, compared to IFN $\gamma+$ TNF $\alpha$ (Fig. 10).

\section{Discussion}

Our results demonstrate that $\mathrm{V}_{2} \mathrm{O}_{5}$ stimulates the secretion of the CXCL8 chemokine, and of the IFN $\gamma$ dependent chemokine CXCL11, in dermal fibroblasts, without altering their viability 


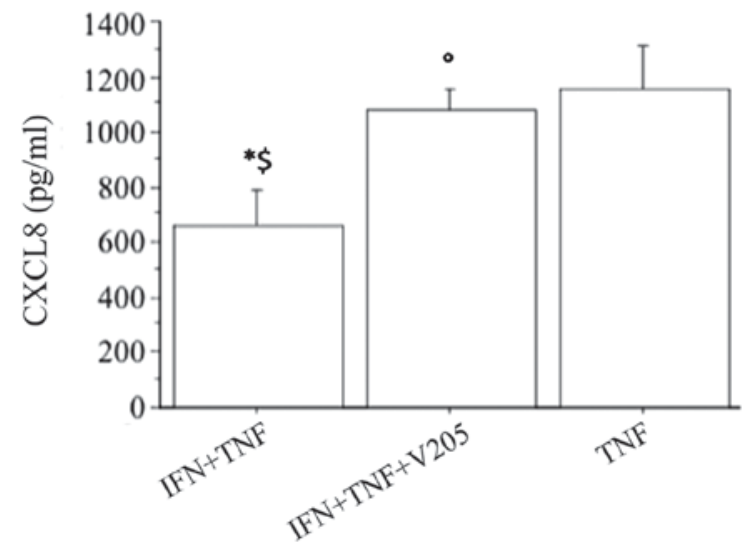

Figure 7. Treatment of dermal fibroblasts with $\mathrm{V}_{2} \mathrm{O}_{5}(100 \mathrm{nM})+\mathrm{IFN} \gamma+\mathrm{TNF} \alpha$ stimulation significantly increased CXCL8 release (the Bonferroni-Dunn test was used for post-hoc comparison; ${ }^{*} \mathrm{P}<0.05$ vs. IFN+TNF+ $\mathrm{V}_{2} \mathrm{O}_{5} ;{ }^{\$} \mathrm{P}<0.05$ vs. TNF; ${ }^{\circ} \mathrm{P}<0.05$ vs. IFN+TNF). $\mathrm{V}_{2} \mathrm{O}_{5}$, vanadium pentoxide; TNF, tumor necrosis factor; IFN, interferon.

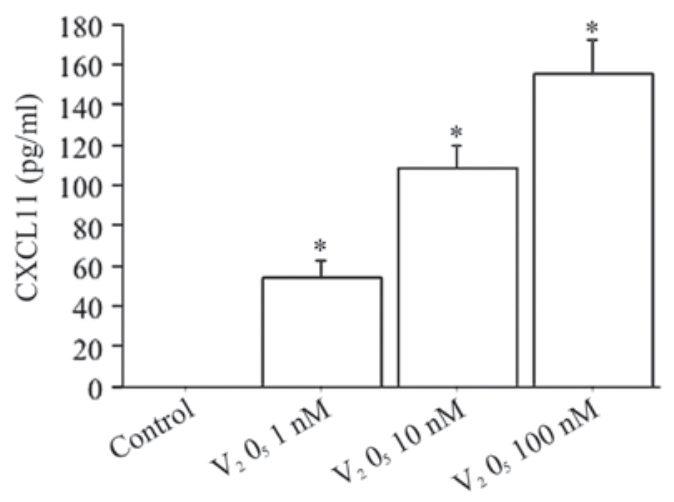

Figure 8. CXCL11 release was dose-dependently stimulated by treating dermal fibroblasts with $\mathrm{V}_{2} \mathrm{O}_{5}(1,10$ and $100 \mathrm{nM})$. ${ }^{*} \mathrm{P}<0.05$ vs. the control (the Bonferroni-Dunn test was used for post-hoc comparison). $\mathrm{V}_{2} \mathrm{O}_{5}$, vanadium pentoxide.

and proliferation. Moreover, our study confirms that IFN $\gamma$ and TNF $\alpha$ stimulated in a different way, the secretion of CXCL8, or CXCL11, chemokines as expected (18). Interestingly, $\mathrm{V}_{2} \mathrm{O}_{5}$ can synergize with IFN $\gamma$ and $\mathrm{TNF} \alpha$, furtherly increasing CXCL11 secretion. In addition, $\mathrm{V}_{2} \mathrm{O}_{5}$ combined with $\mathrm{TNF} \alpha$, elicited a synergistic influence on CXCL8 chemokine production, abolishing the inhibitory effect of IFN $\gamma$.

These results, on the whole, agreed with the view that $\mathrm{V}_{2} \mathrm{O}_{5}$ is able to induce and perpetuate an inflammatory disorder in the dermal tissue inducing inflammatory chemokines secretion (13).

Our findings regarding TNF $\alpha$, and IFN $\gamma$ effect in fibroblasts are in line with the results of another study in a different type of cells. In fact, it has been recently investigated if CXCL8 and CXCL10 chemokines secretion by normal human thyrocytes is dependent upon specific proinflammatory stimuli. CXCL8, but not CXCL10 (an IFN $\gamma$ inducible chemokine, of the same class of CXCL11), was detected in basal conditions. The two chemokines showed differences in their response to proinflammatory cytokines.

Actually, IFN $\gamma$ induced a significant CXCL10 secretion, not obtained with TNF $\alpha$; whereas CXCL8 was secreted in response to $\mathrm{TNF} \alpha$, being instead inhibited by IFN $\gamma$. The

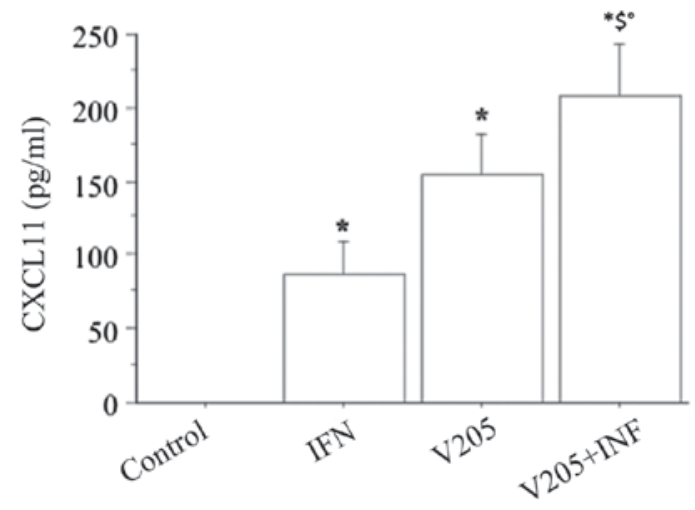

Figure 9. When dermal fibroblasts were treated with $\mathrm{V}_{2} \mathrm{O}_{5}(100 \mathrm{nM})+\mathrm{IFN} \gamma$ CXCL11 release was significantly increased ${ }^{*} \mathrm{P}<0.05$ vs. the control group. ${ }^{\$} \mathrm{P}<0.05$ vs. the IFN group. ${ }^{\circ} \mathrm{P}<0.05$ vs. the $\mathrm{V}_{2} \mathrm{O}_{5}$ group (the Bonferroni-Dunn test was used for post-hoc comparison). $\mathrm{V}_{2} \mathrm{O}_{5}$, vanadium pentoxide; IFN, interferon.

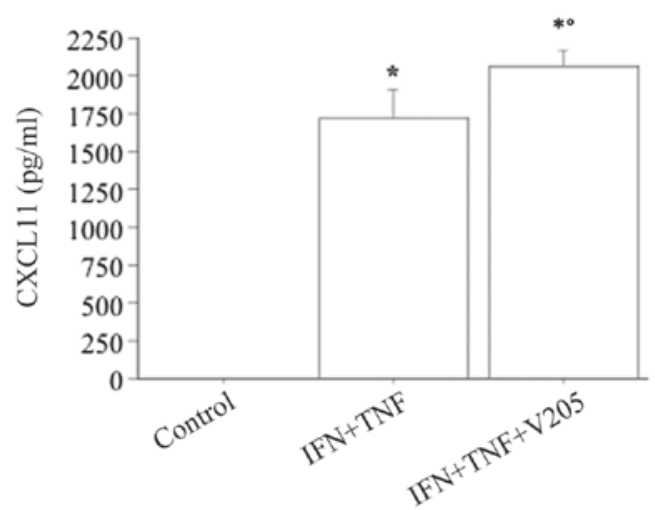

Figure 10. CXCL11 release was significantly increased by treating dermal fibroblasts with $\mathrm{V}_{2} \mathrm{O}_{5}(100 \mathrm{nM})+\mathrm{IFN} \gamma$ and $\mathrm{TNF} \alpha{ }^{*} \mathrm{P}<0.05$ vs. the control group. ${ }^{\circ} \mathrm{P}<0.05$ vs. the IFN+TNF group (the Bonferroni-Dunn test was used for post-hoc comparison). $\mathrm{V}_{2} \mathrm{O}_{5}$, vanadium pentoxide; TNF, tumor necrosis factor; IFN, interferon.

combination of TNFa plus IFN $\gamma$ synergistically increased the IFN $\gamma$-induced CXCL10 secretion, while reversed the TNF $\alpha$-induced CXCL8 secretion (19).

IFN $\gamma$-inducible CXC chemokines can be produced by several types of normal mammalian cells, such as thyrocytes, fibroblasts, colon epithelial cells, islet cells, and others $(10,13,14,19-25)$. However, these cells are not able to produce the CXC chemokines in basal condition, but only when stimulated by cytokines, such as IFN $\gamma$ and TNF $\alpha$, that are released in a T-helper 1 (Th1) type inflammatory site, such as the thyroid at the beginning of Graves' disease, by Th1 activated lymphocytes. It has been suggested that this process can be involved in the initiation and the perpetuation of the inflammation in several autoimmune diseases $(10,13,14,19-25)$, and considering our results it can be applied to the thyroid, too.

Our findings about vanadium stimulation of chemokines agree with those of other studies conducted in different cell types. $\mathrm{V}_{2} \mathrm{O}_{5}$ exposure is a cause of occupational bronchitis; a study evaluated gene expression profiles in human lung fibroblasts (in cultures) after $\mathrm{V}_{2} \mathrm{O}_{5}$ exposure with the aim to identify genes that could be implicated in the bronchial inflammation, repair, and fibrosis in the pathogenesis of bronchitis. Among 
the 10 genes overexpressed by $\mathrm{V}_{2} \mathrm{O}_{5}$, also CXCL8, CXCL9 and CXCL10 were induced (26).

Another study reports that fibroblasts have a role in the innate immune response to vanadium-induced oxidative stress through the synthesis of IFN $\beta$ and the activation of STAT-1 that cause an increase of CXCL10 levels (27).

Interestingly vanadium can increase chemokine secretion in a dose range, from 1 to $100 \mathrm{nM}$. It could be observed that normal blood levels of vanadium are ranging from 0.45 to $18.4 \mathrm{nM}$, and that $100 \mathrm{nM}$ is a dose that might mimick an abnormally high exposure (28). So we could hypothesize that the induction of an inflammatory reaction into the dermal tissue could predispose to the appearance of skin rashes, or atopic dermatitis.

In conclusion our study shows that $\mathrm{V}_{2} \mathrm{O}_{5}$ can induce CXCL8, and CXCL11 chemokines secretion into the dermal fibroblasts. Interestingly, $\mathrm{V}_{2} \mathrm{O}_{5}$ synergistically increased the effect of the IFN $\gamma$ on CXCL11 secretion. Moreover, $\mathrm{V}_{2} \mathrm{O}_{5}$ synergistically increased the effect of the TNF $\alpha$ on CXCL8 secretion, abolishing the inhibitory effect of IFN $\gamma$. Overall CXCL8, and CXCL11 chemokines induction by $\mathrm{V}_{2} \mathrm{O}_{5}$ could lead to the appearance and perpetuation of an inflammatory reaction into the dermal tissue. Further studies are needed to evaluate dermal integrity, and manifestations in subjects occupationally exposed, or living in polluted areas.

\section{Acknowledgements}

Not applicable.

\section{Funding}

No funding was received.

\section{Availability of data and materials}

All data generated or analyzed during this study are included in this published article.

\section{Authors' contributions}

PF, SB, AA and SMF made substantial contributions to the conception and design of the study and to the acquisition of data. All authors analyzed the data. PF, SB, AA and SMF drafted the manuscript. AA revised the manuscript. All authors read and approved the manuscript and agree to be accountable for all aspects of the research in ensuring that the accuracy or integrity of any part of the study are appropriately investigated and resolved. All authors read and approved the final manuscript.

\section{Ethics approval and consent to participate}

Written informed consent was obtained from all study participants and the study was approved by the University of Pisa Ethics Committee.

\section{Consent for publication}

Written informed consent was obtained from all participants for the publication of their data.

\section{Competing interests}

The authors declare that they have no competing interests.

\section{References}

1. Occupational Safety and Health Administration: Occupational Safety and Health Guidelines for Vanadium Pentoxide. https:// www.osha.gov/SLTC/metalsheavy/vanadium.html. Accessed October 29, 2017.

2. Sax NI: Dangerous Properties of Industrial Materials. 6th edition. Van Nostrand Reinhold Company, New York, NY, pp2717-2720, 1984.

3. Ress NB, Chou BJ, Renne RA, Dill JA, Miller RA, Roycroft JH, Hailey JR, Haseman JK and Bucher JR: Carcinogenicity of inhaled vanadium pentoxide in $\mathrm{F} 344 / \mathrm{N}$ rats and $\mathrm{B} 6 \mathrm{C} 3 \mathrm{~F} 1$ mice. Toxicol Sci 74: 287-296, 2003.

4. Wörle-Knirsch JM, Kern K, Schleh C, Adelhelm C, Feldmann C and Krug HF: Nanoparticulate vanadium oxide potentiated vanadium toxicity in human lung cells. Environ Sci Technol 41: 331-336, 2007.

5. Scibior A, Zaporowska H and Ostrowski J: Selected haematological and biochemical parameters of blood in rats after subchronic administration of vanadium and/or magnesium in drinking water. Arch Environ Contam Toxicol 51: 287-295, 2006.

6. González-Villalva A, Fortoul TI, Avila-Costa MR Piñón-Zarate G, Rodriguez-Laraa V, Martínez-Levy G, Rojas-Lemus M, Bizarro-Nevarez P, Díaz-Bech P, Mussali-Galante P and Colin-Barenque L: Thrombocytosis induced in mice after subacute and subchronic V2O5 inhalation. Toxicol Ind Health 22: 113-116, 2006.

7. Kobayashi K, Himeno S, Satoh M, Kuroda J, Shibata N, Seko Y and Hasegawa T: Pentavalent vanadium induces hepatic metallothionein through interleukin-6-dependent and -independent mechanisms. Toxicology 228: 162-170, 2006.

8. Soazo M and Garcia GB: Vanadium exposure through lactation produces behavioral alterations and CNS myelin deficit in neonatal rats. Neurotoxicol Teratol 29: 503-510, 2007.

9. Barceloux DG: Vanadium. J Toxicol Clin Toxicol 37: 265-278, 1999.

10. Antonelli A, Ferri C, Fallahi P, Ferrari SM, Frascerra S, Sebastiani M, Franzoni F, Galetta F and Ferrannini E: High values of CXCL10 serum levels in patients with hepatitis C associated mixed cryoglobulinemia in presence or absence of autoimmune thyroiditis. Cytokine 42: 137-143, 2008.

11. Valyasevi RW, Harteneck DA, Dutton CM and Bahn RS: Stimulation of adipogenesis, peroxisome proliferator-activated receptor-gamma (PPARgamma), and thyrotropin receptor by PPARgamma agonist in human orbital preadipocyte fibroblasts. J Clin Endocrinol Metab 87: 2352-2358, 2002.

12. Wang L, Luo J and He S: Induction of MMP-9 release from human dermal fibroblasts by thrombin: Involvement of JAK/STAT3 signaling pathway in MMP-9 release. BMC Cell Biol 8: 14, 2007.

13. Antonelli A, Rotondi M, Fallahi P, Romagnani P, Ferrari SM, Buonamano A, Ferrannini E and Serio M: High levels of circulating CXC chemokine ligand 10 are associated with chronic autoimmune thyroiditis and hypothyroidism. J Clin Endocrinol Metab 89: 5496-5499, 2004.

14. Kemp EH, Metcalfe RA, Smith KA, Woodroofe MN, Watson PF and Weetman AP: Detection and localization of chemokine gene expression in autoimmune thyroid disease. Clin Endocrinol (Oxf) 59: 207-213, 2003.

15. Antonelli A, Bocci G, La Motta C, Ferrari SM, Fallahi P, Fioravanti A, Sartini S, Minuto M, Piaggi S, Corti A, et al: Novel pyrazolopyrimidine derivatives as tyrosine kinase inhibitors with antitumoral activity in vitro and in vivo in papillary dedifferentiated thyroid cancer. J Clin Endocrinol Metab 96: E288-E296, 2011.

16. Antonelli A, Ferrari SM, Fallahi P, Berti P, Materazzi G, Barani L, Marchetti I, Ferrannini E and Miccoli P: Primary cell cultures from anaplastic thyroid cancer obtained by fine-needle aspiration used for chemosensitivity tests. Clin Endocrinol (Oxf) 69: 148-152, 2008.

17. Quent VM, Loessner D, Friis T, Reichert JC and Hutmacher DW: Discrepancies between metabolic activity and DNA content as tool to assess cell proliferation in cancer research. J Cell Mol Med 14: 1003-1013, 2010. 
18. Antonelli A, Ferrari SM, Fallahi P, Frascerra S, Santini E, Franceschini SS and Ferrannini E: Monokine induced by interferon gamma (IFNgamma) (CXCL9) and IFNgamma inducible T-cell alpha-chemoattractant (CXCL11) involvement in Graves' disease and ophthalmopathy: Modulation by peroxisome proliferator-activated receptor-gamma agonists. J Clin Endocrinol Metab 94: 1803-1809, 2009.

19. Rotondi M, Coperchini F, Pignatti P, Sideri R, Groppelli G, Leporati P, La Manna L, Magri F, Mariotti S and Chiovato L: Interferon- $\gamma$ and tumor necrosis factor- $\alpha$ sustain secretion of specific CXC chemokines in human thyrocytes: A first step toward a differentiation between autoimmune and tumor-related inflammation? J Clin Endocrinol Metab 98: 308-313, 2013.

20. Antonelli A, Ferrari SM, Frascerra S, Pupilli C, Mancusi C, Metelli MR, Orlando C, Ferrannini E and Fallahi P: CXCL9 and CXCL11 chemokines modulation by peroxisome proliferator-activated receptor-alpha agonists secretion in Graves' and normal thyrocytes. J Clin Endocrinol Metab 95: E413-E420, 2010.

21. Garcià-Lòpez MA, Sancho D, Sànchez-Madrid F and Marazuela M: Thyrocytes from autoimmune thyroid disorders produce the chemokines IP-10 and Mig and attract CXCR3+ lymphocytes. J Clin Endocrinol Metab 86: 5008-5016, 2001.

22. Antonelli A, Ferrari SM, Corrado A, Ferrannini E and Fallahi P: CXCR3, CXCL10 and type 1 diabetes. Cytokine Growth Factor Rev 25: 57-65, 2014.
23. Antonelli A, Ferrari SM, Giuggioli D, Ferrannini E, Ferri C and Fallahi P: Chemokine (C-X-C motif) ligand (CXCL)10 in autoimmune diseases. Autoimmun Rev 13: 272-280, 2014.

24. Antonelli A, Fallahi P, Delle Sedie A, Ferrari SM, Maccheroni M, Bombardieri S, Riente L and Ferrannini E: High values of Th1 (CXCL10) and Th2 (CCL2) chemokines in patients with psoriatic arthtritis. Clin Exp Rheumatol 27: 22-27, 2009.

25. Fallahi P, Ferrari SM, Ruffilli I, Elia G, Biricotti M, Vita R, Benvenga S and Antonelli A: The association of other autoimmune diseases in patients with autoimmune thyroiditis: Review of the literature and report of a large series of patients. Autoimmun Rev 15: 1125-1128, 2016.

26. Ingram JL, Antao-Menezes A, Turpin EA, Wallace DG, Mangum JB, Pluta LJ, Thomas RS and Bonner JC: Genomic analysis of human lung fibroblasts exposed to vanadium pentoxide to identify candidate genes for occupational bronchitis. Respir Res 8: 34, 2007.

27. Antao-Menezes A, Turpin EA, Bost PC, Ryman-Rasmussen JP and Bonner JC: STAT-1 signaling in human lung fibroblasts is induced by vanadium pentoxide through an IFN-beta autocrine loop. J Immunol 180: 4200-4207, 2008.

28. Sabbioni E, Kuèera J, Pietra R and Vesterberg O: A critical review on normal concentrations of vanadium in human blood, serum, and urine. Sci Total Environ 188: 49-58, 1996. 